\title{
Bartłomiej CZYŻEWSKI*
}

\section{POLSKA CHRZEŚCIJAŃSKA KASA BEZPROCENTOWA W UNIEJOWIE}

\begin{abstract}
Zarys treści: Przedmiotem niniejszego artykułu jest analiza znajdujących się w zasobach Archiwum Państwowego w Poznaniu dokumentów związanych z działalnością Polskiej Chrześcijańskiej Kasy Bezprocentowej w Uniejowie.
\end{abstract}

Słowa kluczowe: Uniejów, chrześcijańska kasa bezprocentowa, instytucja finansowa

\section{RYS HISTORYCZNY ROZWOJU INSTYTUCJI FINANSOWYCH}

Od zarania dziejów ludzie starali się zgromadzić, a następnie zabezpieczyć swój majątek przed jego utratą. W tym celu władcy i najbogatsi budowali okazałe skarbce i zatrudniali wieloosobowe oddziały, które miały strzec zebranych skarbów. Biedniejsza ludność podczas różnych zawieruch najczęściej ukrywała swój dobytek, np. zakopując go w naczyniach w pobliżu domu. Ludzie pragnęli nie tylko gromadzić i chronić swoje skarby, ale również pomnażać swój majątek. Pozwalało na to nie tylko umiejętne inwestowanie np. poprzez zakupy kolejnych wsi, dzierżawę mennic itp., ale również korzystanie z różnych operacji i instytucji finansowych, które zwiększały kapitał.

Pierwsze tego typu operacje finansowe znane były już w starożytności. Świadczą o tym zachowane gliniane tabliczki z III-II w. p.n.e. z terenów Mezopotamii, na których zapisano transakcje polegające na udzielaniu pożyczek, przechowywaniu depozytów oraz handlu kruszcem. W tym okresie pojawiła się również bezgotówkowa forma obiegu pieniądza zbliżona do dzisiejszego weksla. W czasach antycznych powstały także pierwsze prywatne quasi-banki oraz kredyty hipoteczne. Wszystkie te instytucje rozwijały się przez kolejne stulecia i były przejmowane przez następne imperia i władców, od świata Mezopotamii do Grecji i Rzymu, by potem przez Bizancjum trafić do ludów arabskich ${ }^{1}$. Właśnie za pośrednictwem Arabów trafiły one z kolei, po kilku wiekach zapomnienia, na tereny Italii, do włoskich państw-miast, gdzie w 1156 r. w Wenecji powstał

* Bartłomiej Czyżewski, mgr prawa, asystent sędziego w Sądzie Okręgowym w Łodzi, członek Towarzystwa Genealogicznego Centralnej Polski.

${ }^{1}$ http://encyklopedia.pwn.pl/haslo/banki;3874100 (dostęp: 12.02.2016). 
pierwszy bank ${ }^{2}$. Były to jednak instytucje prywatne, prowadzone głównie przez ludność żydowską; publiczne pojawiły się dopiero pod koniec średniowiecza, a np. banki państwowe dopiero w XVII w. ${ }^{3}$ Poza bankami zaczęły upowszechniać się weksle, depozyty podróżne, oprocentowane pożyczki i inne formy obiegu pieniądza i towarów. Z biegiem kolejnych stuleci powstawały także inne instytucje finansowe, takie jak fundusze, kasy oszczędnościowe czy lombardy.

W Polsce początków operacji i instytucji finansowych należałoby szukać jeszcze w czasach przedpaństwowych, kiedy tereny zajmowane przez naszych przodków odwiedzali obcy kupcy, zajmujący się obrotem towarów oraz pieniądza. Być może to właśnie wtedy udzielono po raz pierwszy w naszej historii pożyczki. W okresie Średniowiecza do Królestwa Polskiego zawitali Żydzi i na długie stulecia to oni praktycznie w całości zajęli się handlem, dawaniem kredytów oraz w późniejszym okresie bankowością. Jednak nie tylko ludność żydowska zajmowała się tą działalnością, trudniło się nią także duchowieństwo, mieszczaństwo oraz w ograniczonym stopniu stan szlachecki. Rozwój ówczesnych instytucji finansowych doprowadził do uchwalenia w $1588 \mathrm{r}$. konstytucji sejmowej regulującej pierwszeństwo zapisów hipotecznych, a w dniu 13 kwietnia 1775 r. konstytucji sejmowej zatytułowanej „Ustanowienie prawa wekslowego”4. Również na okres tzw. I Rzeczypospolitej przypadł rozwój i rozkwit bankowości prywatnej. Powstały prywatne banki żydowskie oraz chrześcijańskie banki pobożne ${ }^{5}$. Natomiast pomysł utworzenia banku państwowego pojawił się w trakcie obradowania Sejmu Czteroletniego (1788-1792)6. Realizacja tej idei nastąpiła jednakże dopiero w 1828 r. dzięki staraniom ministra skarbu Królestwa Kongresowego księcia Ksawerego Druckiego-Lubeckiego?

W czasie zaborów na ziemiach polskich obowiązywały odmienne systemy prawne i regulacje dla terenów wcielonych do Królestwa Prus, Cesarstwa Austrii, Imperium Rosyjskiego oraz dla Królestwa Kongresowego istniejącego w ramach monarchii rosyjskiej. W związku z tym, po odzyskaniu niepodległości przez Polskę w 1918 r., jednym z najważniejszych zadań było opracowanie i przyjęcie ujednoliconego oraz zunifikowanego dla terenów całego państwa prawa, również w zakresie handlowym, gospodarczym i dotyczącym instytucji finansowych.

Jednak w okresie międzywojennym polski ustawodawca nie zawarł w żadnym akcie prawnym definicji tego rodzaju instytucji, mimo że samo określenie ,instytucja finansowa” pojawia się kilkanaście razy w różnych ustawach,

${ }^{2}$ T. Manteuffel, Historia powszechna. Średniowiecze, PWN, Warszawa 2016, s. 267

${ }^{3}$ J. Besala, Banki i bańki, „Polityka”, nr 3 (2842) z dnia 18 stycznia 2012 r., s. 56-57; http:// www.polityka.pl/tygodnikpolityka/historia/1523347,3,historia-bankow-i-bankierow.read (dostęp: 12.02.2016).

${ }^{4}$ S. Bratkowski, Nieco inna historia cywilizacji. Dzieje banków, bankierów i obrotu pieniężnego, VEDA Agencja Wydawnicza, Warszawa 2010, s. 238, 241.

${ }^{5}$ http://www.fakt.pl/historia-pieniadza/jak-ksztaltowala-sie-bankowosc-prywatna-w-polsce,artykuly,489722.html (dostęp: 12.02.2016).

${ }^{6}$ C. Leszczyńska, Zarys historii polskiej bankowości centralnej, Narodowy Bank Polski, Warszawa 2010, s. 7.

${ }^{7}$ Tamże, s. 9. 
dekretach i rozporządzeniach ${ }^{8}$. Próżno więc szukać jakiegokolwiek wyjaśnienia, czym są instytucje finansowe czy też jaki jest zakres ich działalności w mniejszych regulacjach. Nie natrafimy też na nie w tak kompleksowych i dużych aktach prawnych jak prawo bankowe z 1928 r. czy Kodeks handlowy z 1934 r. Co ciekawe, mimo użycia tego określenia w art. $648 \S 3$ i art. $654 \S 2$ pkt 8 wyżej wymienionego Kodeksu ${ }^{9}$ (dotyczących domów składowych) i połączenia go bezpośrednio z bankiem domicylowym, zabieg ten uznać należy wyłącznie za stylistyczno-językowy, gdyż nie tylko ustawodawca nie odnosi się nigdzie więcej do ,instytucji finansowych”, ale również ówcześni prawnicy w swoich komentarzach do Kodeksu całkowicie pomijają ten zwrot i w żaden sposób się nim nie zajmują ${ }^{10}$. Analizując jednakże ogół aktów prawnych z okresu międzywojennego, można wyprowadzić wniosek, że za instytucje finansowe uważano wtedy instytucje udzielające pożyczek, kredytów oraz takie, które mogły emitować listy zastawne i obligacje. Takimi instytucjami były m.in. banki dewizowe, banki domicylowe czy towarzystwa kredytowe.

Do prawa polskiego definicję instytucji finansowych wprowadziły dopiero Prawo bankowe z 1997 r., definiujące międzynarodowe instytucje finansowe oraz Kodeks spółek handlowych z 2000 r., określający instytucje finansowe. Obydwie regulacje obowiązują do dzisiaj i nadal definiują interesujące nas pojęcia $^{11}$, przy czym Prawo bankowe zawiera definicje międzynarodowej instytucji finansowej oraz instytucji finansowej.

Odwołując się do literatury przedmiotu, instytucje finansowe można podzielić na instytucje bankowe oraz instytucje o charakterze niebankowym. Instytucje bankowe to te, które oferują usługi w zakresie dokonywania rozliczeń pieniężnych, finansowania działalności poprzez udzielanie kredytów oraz lokowania wolnych środków pieniężnych w formie depozytów ${ }^{12}$ (m.in. bank centralny, banki komercyjne, banki spółdzielcze). Natomiast instytucje o charakterze niebankowym świadczą usługi podobne do oferowanych przez banki, ale bez usług depozytowych (m.in. kasy oszczędnościowe, fundusze emerytalne, fundusze

${ }^{8}$ Między innymi w ustawie w przedmiocie upoważnienia Ministra Skarbu do udzielania kooperatywom pracowników państwowych pomocy finansowej z dnia z dnia 13 lipca 1920 r. (Dz.U. $\mathrm{Nr}$ 62, poz. 399), rozporządzeniu Prezydenta Rzeczypospolitej w sprawie zmian w ustawie z dnia 10 czerwca 1921 r. w przedmiocie utworzenia Państwowego Banku Rolnego z dnia 14 maja 1924 r. (Dz.U. Nr 43, poz. 450), rozporządzeniu Ministra Skarbu w sprawie zmiany statutu Towarzystwa Kredytowego Przemysłu Polskiego z dnia 31 grudnia 1927 r. (Dz.U. 1928 Nr 7, poz. 49), dekrecie Prezydenta Rzeczypospolitej o zmianie rozporządzenia Prezydenta Rzeczypospolitej z dnia 22 kwietnia 1927 r. o rozbudowie miast z dnia 14 stycznia 1936 r. (Dz.U. Nr 3, poz. 9).

${ }^{9}$ Rozporządzenie Prezydenta Rzeczypospolitej Kodeks handlowy z dnia 27 czerwca 1934 r. (Dz.U. Nr 57, poz. 502).

${ }^{10}$ M. Allerhand, Kodeks handlowy. Komentarz, „Kodeks” Spółka wydawnicza, Lwów 1935, s. 954-955, 962-966; A. Kon, Kodeks handlowy. Komentarz, Księgarnia F. Hoesicka, Warszawa 1934, s. 260, 262-263.

${ }^{11}$ Stan prawny na dzień 12 lutego $2016 \mathrm{r}$.

${ }^{12}$ M. Białasiewicz, S. Marek, Podstawy nauki o organizacji: Przedsiębiorstwo jako organizacja gospodarcza, Polskie Wydawnictwo Ekonomiczne, Warszawa 2008, s. 94. 
powiernicze, firmy maklerskie, giełdy pieniężne). Można więc śmiało przyjąć zgodnie z definicją zamieszczoną w Stowniku finansów i bankowości, że instytucje finansowe są to organizacje, których głównym celem działania jest świadczenie usług finansowych i doradztwa w odniesieniu do produktów finansowych ${ }^{13}$.

Mimo tak szerokiego spektrum podmiotów próżno jednak szukać wśród dzisiejszych instytucji finansowych kas kredytu bezprocentowego (znanych również pod nazwą kas bezprocentowych pożyczek), które istniały i cieszyły się dużą popularnością w okresie II Rzeczypospolitej Polskiej. Jednakże kasy te nie są polskim tworem. Ich początku należy upatrywać w powołaniu w dniu 27 listopada 1914 r. w Stanach Zjednoczonych American Jewish Joint Distribution Comitee (AJJDC). Pierwotnie celem tej instytucji miała być pomoc Żydom zamieszkującym na terenach centralnej i wschodniej Europy oraz Bliskiego Wschodu, borykającym się z problemem głodu. Na skutek działań wojennych w okresie I wojny światowej, późniejszej inflacji oraz kryzysu gospodarczego AJJDC objęła swym działaniem również ludność żydowską dotkniętą tymi problemami ${ }^{14}$. W Polsce organizacja ta pojawiła się po 1918 r., a w 1923 r. nabyła Bank Rosyjsko-Polski S.A., który do 1925 r. kierował akcją charytatywną organizacji. Po wybuchu kryzysu gospodarczego jesienią 1925 r. AJJDC utworzył na terenach Polski sieć kas bezprocentowego kredytu. Miały one za zadanie wspierać drobny przemysł i rzemiosło ludności żydowskiej ${ }^{15}$. W dniu 1 stycznia 1927 r. kas tego rodzaju istniało 226, rok później $504^{16}$, natomiast w 1936 r. aż $826^{17}$.

Były to jednak kasy, do których zgłosić się mogła wyłącznie ludność żydowska. W związku z tym w trakcie Zjazdu Rady Związku Izb Rzemieślniczych w dniu 9 grudnia 1935 r. podjęto decyzję o zorganizowaniu pierwszych chrześcijańskich kas bezprocentowych. Zbigniew Ehrenberg w referacie wygłoszonym podczas zjazdu delegatów chrześcijańskich kas bezprocentowych w 1937 r. tak opisywał początki tworzenia tych instytucji: „Mając niejako wytyczne, rzemiosło w terenie rozpoczęło akcję organizacyjną, tak, że dziś już szereg kas bezprocentowego kredytu rzemiosła chrześcijańskiego uzyskało zatwierdzenie władz nadzorczych, a spora liczba tych kas jest w stadium organizowania. Równolegle i niezależnie od akcji na terenie rzemieślniczym prowadzona była akcja na terenie kupieckim oraz w innych organizacjach bądź społecznych bądź charytatywnych. Akcją tą zainteresowało się również nasze duchowieństwo i przy licznych parafiach funkcjonują również kasy kredytu bezprocentowego" "18. Idea chrześcijańskich kas kredytu bezprocentowego spotkała się więc z dużym zainteresowaniem

\footnotetext{
${ }^{13}$ Stownik finansów i bankowości, Wydawnictwo Naukowe PWN, Warszawa 2008, s. 140.

${ }^{14} \mathrm{http}: / /$ www.ushmm.org/wlc/en/article.php?ModuleId=10005367 (dostęp: 12.02.2016).

${ }^{15}$ W. Morawski, Stownik historyczny bankowości polskiej do 1939 r., Wydawnictwo Muza S.A., Warszawa 1998, s. 85.

${ }^{16} \mathrm{~J}$. Bornstein, Kasy Bezprocentowych Pożyczek w Polsce, „Kwartalnik Statystyczny”, t. V, z. 3, Główny Urząd Statystyczny Rzeczypospolitej Polskiej, Warszawa 1928, s. 1243.

${ }^{17}$ W. Morawski, dz. cyt., s. 86.

${ }^{18}$ Chrześcijańskie Kasy Bezprocentowego Kredytu, Związek Rzemieślników Chrześcijan w Warszawie, Warszawa 1937, s. 5.
} 
i szybko powstały organizacje zrzeszające już działające kasy. Jak podaje Wojciech Morawski: „W sierpniu 1936 roku powstała w Warszawie Polska Centralna Kasa Kredytu Bezprocentowego, w marcu 1937 roku - Zjednoczenie Chrześcijańskich Kas Bezprocentowego Kredytu w Rzeczypospolitej Polskiej. Wkrótce utworzono jeszcze jedną, regionalną centralę - Związek Pomorskich Kas Bezprocentowego Kredytu. Centralna Kasa skupiała kasy na zasadzie terytorialnej, zjednoczenie - raczej według klucza branżowego. W 1937 roku powstało łącznie 198 kas $^{19}$, natomiast w 1938 roku istniały 382 kasy: 223 zrzeszone w Centralnej Kasie, 121 w Zjednoczeniu i 38 w Związku Pomorskim" "20.

Przedmiotem działalności powstałych w okresie II Rzeczypospolitej Polskiej kas kredytu bezprocentowego było udzielanie biednej ludności nieoprocentowanych kredytów (pożyczek) na cele związane z prowadzoną działalnością gospodarczą bądź rzemieślniczą. Kredyty te wydawane były na okres od 3 miesięcy do maksymalnie roku, a ich wysokość była uzależniona od kapitału obrotowego konkretnej kasy, np. przy kapitale do 10.000 zł można było otrzymać kredyt w maksymalnej wysokości 100 zł, przy kapitale 50.000 zł - 200 zł, przy $100.000 \mathrm{zł}-300$ i $500 \mathrm{zt}^{21}$. Ponadto kasy zajmowały się udzielaniem fachowych porad dotyczących zakładania i prowadzenia działalności, urządzały kursy i wykłady zawodowe oraz organizowały imprezy mające na celu powiększenie dochodu kasy.

\section{POLSKA CHRZEŚCIJAŃSKA KASA BEZPROCENTOWA W UNIEJOWIE}

W Archiwum Państwowym w Poznaniu w zespole „Urząd Wojewódzki Poznański”, seria „Stowarzyszenia - instytucje finansowe” zebrane są dokumenty z szeregu Kas Bezprocentowych istniejących na terenie przedwojennego województwa poznańskiego. Między innymi zachowane są teczki z Dobrej koło Turku, Kostrzyna, Poznania czy Wrześni. W zespole tym znajduje się również niewielki zbiór dokumentów dotyczący istniejącej w Uniejowie Polskiej Chrześcijańskiej Kasy Bezprocentowej ${ }^{22}$. Zgodnie z opisem jednostki dokumenty znajdujące się w niej zostały sporządzone w latach 1937-1938.

Zespół archiwalny otwiera pismo Starosty Powiatowego Tureckiego Stanisława Nożyńskiego ${ }^{23}$ z dnia 10 grudnia 1936 r., skierowane do Urzędu Wojewódzkiego Wydziału Społeczno-Politycznego w Łodzi. Starosta w załączeniu

${ }^{19}$ W.F., Bezprocentowe Kasy Pożyczkowe, „Samodzielność”, nr 19 z dnia 1 października 1938 r., s. 1 [autor anonimowy].

${ }^{20}$ W. Morawski, dz. cyt., s. 86.

${ }^{21}$ J. Bornstein, dz. cyt., s. 1241.

${ }^{22}$ Archiwum Państwowe w Poznaniu, Urząd Wojewódzki Poznański, Polska Chrześcijańska Kasa Bezprocentowa w Uniejowie powiatu tureckiego, sygn. 1060 (mikrofilm nr O-47584); cały zespół został zdigitalizowany i udostępniony na portalu szukajwarchiwach.pl.

${ }^{23}$ Starosta turecki w latach 1933-1937, prezes kilku organizacji w Turku, działacz społeczny i kulturalny (przyp. autora). 
przedkłada akta dotyczące rejestracji „Polskiej Chrześcijańskiej Kasy Bezprocentowej w Uniejowie" z prośbą o jej zarejestrowanie ${ }^{24}$.

Kolejny dokument w zespole stanowi pismo założycieli uniejowskiej Kasy wniesione do Urzędu Wojewódzkiego w Łodzi za pośrednictwem Starostwa Powiatowego w Turku, złożone w Starostwie w dniu 26 listopada 1936 r. Składający zwracają się z uprzejmą prośbą o zarejestrowanie stowarzyszenia Polskiej Chrześcijańskiej Bezprocentowej Kasy w Uniejowie oraz załączają 4 egzemplarze statutu stowarzyszenia, protokół zebrania organizacyjnego z dnia 8 listopada 1936 r. oraz dane personalne założycieli. Jednocześnie składający oświadczyli, że upoważniają księdza kanonika Leonarda Stawickiego ${ }^{25}$ do udzielania władzom wszelkich wyjaśnień potrzebnych w sprawie stowarzyszenia oraz wprowadzania w statucie wszelkich żądanych przez władze poprawek i zmian. Wskazano także, że tymczasową siedzibą Komitetu Założycieli będzie probostwo w Uniejowie. Na końcu pisma znajdują się podpisy 16 osób - założycieli Kasy ${ }^{26}$.

Następnym dokumentem jest protokół zebrania organizacyjnego stowarzyszenia Polskiej Chrześcijańskiej Bezprocentowej Kasy w Uniejowie o następującej treści:

\section{„PROTOKÓŁ}

zebrania organizacyjnego stowarzyszenia «Polskiej Chrześcijańskiej Kasy Bezprocentowej w Uniejowie», odbytego w dniu 8 listopada, o godzinie 4 po poł., w lokalu Domu Katolickiego przy ulicy Kościelnickiej w Uniejowie.

Przybyło na zebranie 45 niżej podpisanych. 16 jako założyciele.

Po zagajeniu przez p. Ks. Kan. L. Stawickiego na przewodniczącego zebrania jednogłośnie wybrano p. Bagińskiego Bronisława, na sekretarza p. Rysztokiego Wiktora.

Odczytano projekt statutu Stowarzyszenia: «Polska Chrześcijańska Kasa Bezprocentowa w Uniejowie» i po przeprowadzeniu dyskusji jednogłośnie powzięto następujące uchwały:

1. postanowiono założyć stowarzyszenie pod nazwą «Polska Chrześcijańska Kasa Bezprocentowa w Uniejowie» z siedzibą w Uniejowie, z obszarem działalności na terenie Uniejowa i gmin: Kościelnica, Skotniki, Niewiesz, Niemysłowa, Zelgoszcz, Biernacice i Wola Świnecka

2. akceptowano tekst statutu zgodny z odczytanym na zebraniu projektem statutu przesłanym przez Polską Centralną Kasę Kredytu Bezprocentowego w Warszawie

${ }^{24}$ Archiwum Państwowe w Poznaniu, Urząd Wojewódzki Poznański, Polska Chrześcijańska Kasa, dz. cyt., s. 1.

${ }^{25}$ Proboszcz parafii w Uniejowie w latach 1932-1939, działał społecznie i politycznie; aresztowany przez władze niemieckie 6 października 1941 r. i wywieziony do KL Dachau, zginął 28 maja 1942 r. w KL Dachau albo w ośrodku eutanazji Schloss Hartheim koło Linzu (przyp. autora).

${ }^{26}$ Archiwum Państwowe w Poznaniu, Urząd Wojewódzki Poznański, Polska Chrześcijańska Kasa, dz. cyt., s. 2-3. 
3. upoważniono p. Ks. Kan. L. Stawickiego zamieszkałego w Uniejowie do działania w imieniu wszystkich podpisanych: a) celem zarejestrowania wymienionego stowarzyszenia, w szczególności do udzielania w tej sprawie zarejestrowania Władzom potrzebnych Im wyjaśnień i wprowadzania w statucie poprawek i zmian żądanych przez Władze, b) celem zwołania pierwszego walnego zebrania.

Przewodniczący zamknął zebranie o godzinie 5 po poł. poczem obecni podpisują niniejszy protokół.

Przewodniczący: /podpis/ Sekretarz: /podpis/

/podpisy założycieli/"’27.

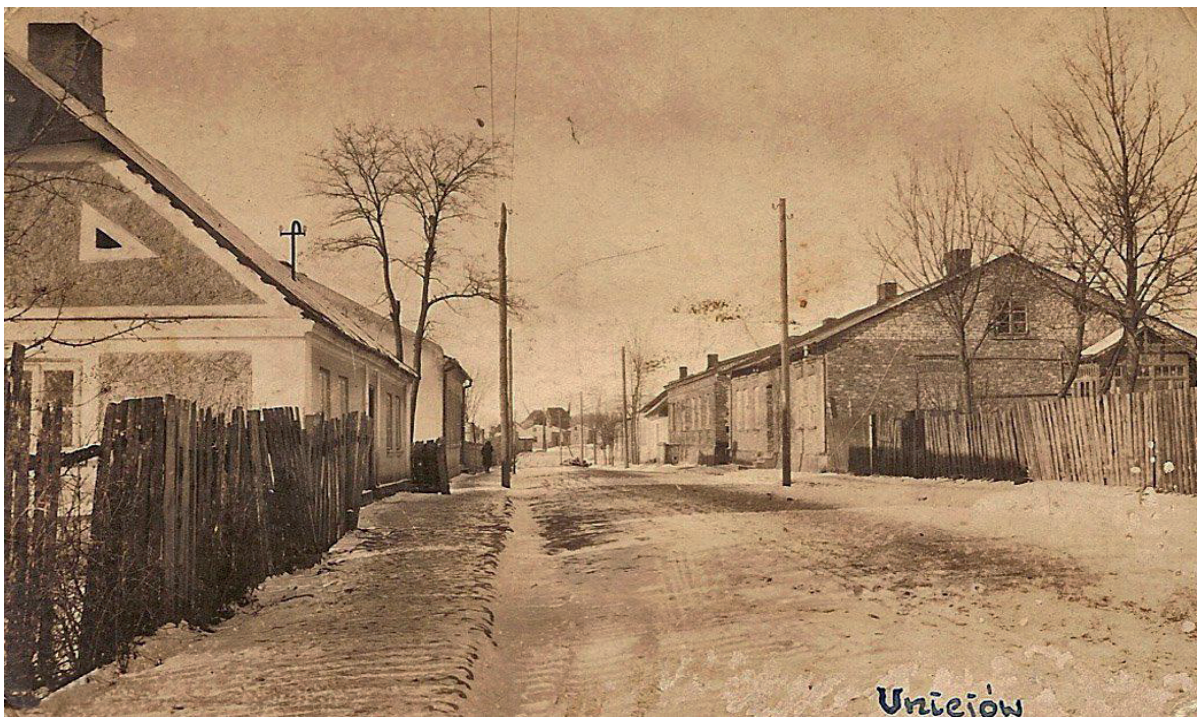

Ryc. 1. Widok ulicy Kościelnickiej z ok. 1936 r., przy której znajdowała się siedziba Kasy Źródło: własność Jadwigi Wysockiej

Jak wskazują dalsze dokumenty, wszyscy założyciele Polskiej Chrześcijańskiej Kasy Bezprocentowej w Uniejowie jeszcze przed jej zarejestrowaniem zostali szczegółowo sprawdzeni przez właściwe organy. Podstawą takiej weryfikacji było pismo Starosty Powiatowego Tureckiego z dnia 26 listopada 1936 r., skierowane do Posterunku Policji Państwowej w Uniejowie, aby w terminie do 10 grudnia 1936 r. zostały przesłane wyczerpujące opinie o wszystkich szesnastu założycielach $\mathrm{Kasy}^{28}$. Policja $\mathrm{z}$ postawionego przed nią zadania wywiązała się zdecydowanie przed terminem, albowiem już 5 grudnia 1936 r. zostało przygotowane dla Starostwa pismo zawierające szczegółowe dane o twórcach Polskiej Chrześcijańskiej Kasy Bezprocentowej w Uniejowie. Na podstawie tego dwustronicowego dokumentu można nie tylko poznać dane metrykalne każdego

\footnotetext{
${ }^{27}$ Tamże, s. 4-5.

${ }^{28}$ Tamże, s. 6.
} 
z założycieli (rodzice, data urodzenia), ale także dowiedzieć się, gdzie mieszkali w 1936 r. i czym się zajmowali. Policja odnotowała także informacje o wyznaniu każdego z twórców Kasy, jaki posiadali majątek i z czego się utrzymywali, jaką cieszyli się opinią, czy byli karani sądowo bądź administracyjnie, jaki jest ich stosunek do władz, jakie są ich zapatrywania polityczne oraz czy są/były prowadzone przeciwko nim jakieś śledztwa za przestępstwa polityczne lub kryminalne. Nie wskazano jednak, z jakich źródeł korzystała Policja, gromadząc wszystkie te informacje. Mając wszakże na uwadze ich zakres oraz treść, można przypuszczać, że zostały one ustalone na podstawie prowadzonych przez Policję rejestrów oraz wywiadów środowiskowych.

W tym miejscu warto przytoczyć zebrane przez Policję dane metrykalne założycieli PChKB w Uniejowie: 1869 r.,

1. ks. Leonard Stawicki - syn Sylwestra i Stanisławy, ur. 25 października

2. Bronisław Bagiński - syn Piotra i Marii, ur. 4 lutego 1886 r.,

3. Andrzej Zachorowski - syn Wilhelma i Izabeli, ur. 30 listopada 1883 r.,

4. Juliusz Ponsyliusz - syn Ernesta i Anieli, ur. 13 kwietnia 1881 r.,

5. Józef Andrzejewski - syn Stanisława i Marianny, ur. 15 kwietnia 1900 r.,

6. Franciszek Tylżon vel Tylżanowski - syn Franciszka i Józefy, ur. 17 lipca 1895 r.,

7. Wacław Zieliński - syn Wacława i Leokadii, ur. 28 marca 1886 r.,

8. Jan Pradzyński - syn Józefa i Marianny, ur. 25 grudnia 1886 r.,

9. Kazimierz Dybowski - syn Władysława i Józefy, ur. 8 stycznia 1895 r.,

10. Władysław Stasiak - syn Stanisława i Józefy, ur. 17 lipca 1900 r.

11. Józef Zieliński - syn Ludwika i Ewy, ur. 28 marca 1897 r.,

12. Józef Bamberski - syn Walentego i Franciszki, ur. 21 stycznia 1880 r.,

13. ks. Wiktor Rysztogi - syn Władysława i Franciszki,

14. Maria Stanisława Bagińska - córka Stanisława i Marii,

15. Jan Oporowicz - syn Antoniego i Marii, ur. w 1897 r.,

16. Antoni Sasiak - syn Antoniego i Stanisławy ${ }^{29}$.

Tak szczegółowa weryfikacja każdego z założycieli uniejowskiej Kasy spowodowana była obawą władz, czy instytucja ta nie stanie się placówką polityczną obozu narodowego. Świadczą o tym dwa dokumenty opatrzone dopiskiem oraz stemplem „Tajne”. Pierwszy stanowi odręczne pismo skierowane do Starosty w Turku. Nadawca zwraca się w nim o przesłanie, na prośbę „NW”, opinii w kwestii rejestracji Kasy w Uniejowie w związku z tym, że kilku członków założycieli należy bądź sympatyzuje ze Stronnictwem Narodowym. W związku z tym istniało ryzyko, że w przyszłości Kasa stanie się placówką polityczną w akcji obozu narodowego. Zwrócono także uwagę, czy zakładanie drugiej Kasy w powiecie ${ }^{30}$ nie będzie wstrzymywało rozwoju tej pierwszej. Co ciekawe, brak $\mathrm{w}$ treści dokumentu wskazania, skąd pismo pochodzi. Wprawdzie podana sygnatura sprawy oraz jej przedmiot, tj. rejestracja Kasy, pojawiają się ponadto w jego

\footnotetext{
${ }^{29}$ Tamże, s. 7-8.

${ }^{30}$ Pierwsza powstała w Turku (przyp. autora).
} 
osnowie skróty w postaci wspomnianego już „NW” oraz na końcu „WWSPP” odnoszące się niewątpliwie do nadawcy, ale brak jest jednoznacznej informacji umożliwiającej jego/ich identyfikację ${ }^{31}$.

Dopiero zapoznanie się z kolejnym pismem pozwala rozpoznać instytucję, z której pochodzi pierwszy dokument. W drugim piśmie (z dnia 8 stycznia 1937 r.) Starosta turecki udziela bowiem Urzędowi Wojewódzkiemu Wydziałowi Społeczno-Politycznemu w Łodzi odpowiedzi na pismo z dnia 22 grudnia 1936 r. Starosta stwierdza w nim, że wprawdzie faktycznie kilku członków założycieli Kasy w Uniejowie popiera Stronnictwo Narodowe, ale nie należy się spodziewać, aby instytucja ta stała się placówką polityczną obozu narodowego, gdyż „Członkowie założyciele o poglądach prorządowych dają gwarancję należytego prowadzenia tej placówki”. W dalszej części Starosta informuje również, że Kasa Bezprocentowa w Turku nie jest w stanie obsłużyć całej ludności zamieszkującej w Uniejowie ${ }^{32}$. Tak więc skrót „WWSPP” należy utożsamiać z Wojewódzkim Wydziałem Spraw Politycznych, a skrót „NW” najprawdopodobniej odnosi się do naczelnika wydziału.

W kolejnym piśmie (z dnia 21 stycznia 1937 r.) skierowanym do Urzędu Wojewódzkiego Wydziału Społeczno-Politycznego w Łodzi, Starosta Powiatowy Turecki informuje, że otrzymał w dniu sporządzenia przedmiotowego pisma telefoniczne zawiadomienie od sekretarza premiera o asygnowaniu dla Chrześcijańskiej Kasy Bezprocentowej w Uniejowie kwoty 1000 złotych na zasilenie funduszów tej kasy. W dalszej części Starosta zwraca się do Wydziału o szybkie zarejestrowanie kasy, stwierdzając, że fakt asygnowania przez premiera ${ }^{33}$ wyżej wymienionej kwoty pieniężnej świadczy o jego osobistym życzeniu, aby taka instytucja w Uniejowie powstała ${ }^{34}$. Chcąc zobrazować, jak duża to była kwota, należy wskazać, że w kwietniu 1937 r. za krowę dojną trzeba było zapłacić 181 zł, za konia roboczego 254 zł, za pług konny 27 zł, a cena maszyny do pisania wynosiła $1.223,90 \mathrm{zt}^{35}$.

Wobec braku przeciwskazań pomiędzy Starostą Tureckim, a łódzkim Urzędem Wojewódzkim nastąpiła wymiana pism zmierzająca do jak najszybszego zarejestrowania Polskiej Chrześcijańskiej Bezprocentowej Kasy w Uniejowie. Ostatnią przeszkodą, jaka stanęła na drodze założycieli Kasy, okazała się kwestia opłacenia kosztów ogłoszenia i rejestracji stowarzyszenia w „Monitorze Polskim" w wysokości 30 złotych. Jak wynika z treści zachowanych dokumentów, początkowo przesłano na ten cel kwotę $20 \mathrm{zł}$, wnosząc o zwolnienie z pozostałej części z uwagi na dobroczynny charakter instytucji. Zgoda na zwolnienie Kasy w Uniejowie z części opłaty nie została finalnie wyrażona, o czym świadczą dwa

${ }^{31}$ Archiwum Państwowe w Poznaniu, Urząd Wojewódzki Poznański, Polska Chrześcijańska Kasa, dz. cyt., s. 9-10.

${ }^{32}$ Tamże, s. 11.

${ }^{33}$ Premierem Polski był wtedy Felicjan Sławoj Składkowski (przyp. autora).

${ }^{34}$ Archiwum Państwowe w Poznaniu, Urząd Wojewódzki Poznański, Polska Chrześcijańska Kasa, dz. cyt., s. 12.

${ }^{35}$ Mały rocznik statystyczny 1937, Główny Urząd Statystyczny Rzeczypospolitej Polskiej, Warszawa 1937, s. 230-231. 
kwity na kwoty 20 zł i 10 zł oraz pismo Urzędu Wojewódzkiego w Łodzi do Polskiej Agencji Telegraficznej „Monitora Polskiego” ze stwierdzeniem, że wpłacono kwotę 30 zł stanowiącą należność za druk ogłoszenia ${ }^{36}$.

Ostatecznie, w dniu 9 lutego 1937 r., na mocy decyzji Wojewody Łódzkiego Polska Chrześcijańska Bezprocentowa Kasa w Uniejowie została wciągnięta do rejestru stowarzyszeń i związków Urzędu Wojewódzkiego Łódzkiego pod nr 1546. We wpisie określono, że terenem działania Kasy są miasto Uniejów oraz gminy Kościelnica, Skotniki, Niewiesz, Niemysłowa i Zelgoszcz. Jako cel stowarzyszenia wskazano „niesienie pomocy niezamożnym Polakom wyznania chrześcijańskiego przez udzielanie bezprocentowych pożyczek", a jako środki działania wymieniono ,udzielanie bezprocentowych pożyczek, podejmowanie imprez dochodowych, urządzanie kursów zawodowych itp.”. Czas istnienia stowarzyszenia oznaczono jako „nieograniczony”37.

Po tych dokumentach w teczce archiwalnej Kasy w Uniejowie znajduje się wizytówka burmistrza Uniejowa Juliusza Stanisława Ponsyliusza ${ }^{38} \mathrm{z}$ odręczną adnotacją, że burmistrz o rejestracji uniejowskiej Kasy został poinformowany w dniu 16 lutego $1937 \mathrm{r}^{39}$

Ponadto, w zachowanym zbiorze dokumentów Polskiej Chrześcijańskiej Kasy Bezprocentowej w Uniejowie znajduje się także jej statut. Jest on standardowym drukiem, przygotowanym i wydanym w Warszawie w 1936 r. nakładem Polskiej Centralnej Kasy Kredytu Bezprocentowego. Zarząd Główny tej instytucji na posiedzeniach w dniach 28 września i 3 października 1936 r. przyjął tekst statutu (wykorzystanego również w Uniejowie), i zalecił go jako statut wzorcowy Chrześcijańskich Kas Bezprocentowych. Dlatego też, statut ów posiadał na stronie tytułowej oraz stronach 1 i 2 specjalnie przygotowane, wykropkowane puste miejsca, które były następnie uzupełniane przez poszczególne, dopiero co zakładane chrześcijańskie kasy kredytu bezprocentowego.

I tak, 18-stronicowy statut regulował nie tylko podstawy prawne działalności kasy, ale także określał szczegółowo cel i zakres jej aktywności. Znajdujemy w nim artykuły dotyczące osobowości prawnej kasy, regulacje odnoszące się do członków i władz kasy, funduszów stowarzyszenia, kwestii zmiany statutu oraz likwidacji stowarzyszenia. Co istotne, głównemu przedmiotowi działalności kasy, czyli udzielaniu pożyczek, poświęcono dwa krótkie artykuły. Sprowadzają się one zasadniczo do stwierdzenia, że bezprocentową pożyczkę mogą otrzymać jedynie Polacy chrześcijanie, a jej zwrot winien nastąpić jednorazowo lub ratalnie. Wszelkie pozostałe szczegółowe zasady udzielania pożyczek miały zostać określone w osobnym regulaminie uchwalonym przez zarząd kasy. W statucie

${ }^{36}$ Archiwum Państwowe w Poznaniu, Urząd Wojewódzki Poznański, Polska Chrześcijańska Kasa, dz. cyt., s. 13-17, 20-21.

37 Tamże, s. 18-19, 41.

${ }^{38}$ Burmistrz Uniejowa w latach 1934-1939, działacz społeczny (przyp. autora).

${ }^{39}$ Archiwum Państwowe w Poznaniu, Urząd Wojewódzki Poznański, Polska Chrześcijańska Kasa, dz. cyt., s. 22. 
uregulowano także sprawy mniejszej wagi i znaleźć tam można np. zapis, że kasa posiada własną pieczątkę ${ }^{40}$.

Po statusie oraz piśmie Urzędu Wojewódzkiego Łódzkiego dotyczącym wpisania uniejowskiej Kasy do rejestru znajduje się pełna lista założycieli Polskiej Chrześcijańskiej Kasy Bezprocentowej w Uniejowie (tab. 1). Każda z osób złożyła na niej pełny, czytelny podpis ${ }^{41}$ (ryc. 2).

Tabela 1. Lista założycieli Polskiej Chrześcijańskiej Kasy Bezprocentowej w Uniejowie

\begin{tabular}{|c|l|l|}
\hline Lp. & \multicolumn{1}{|c|}{ Imię i nazwisko } & \multicolumn{1}{|c|}{ Miejsce zamieszkania } \\
\hline 1. & ks. Leonard Stawicki & Uniejów \\
\hline 2. & Franciszek Tylżanowski & Uniejów \\
\hline 3. & Antoni Sasiak & Kościelnica \\
\hline 4. & Wacław Zieliński & Uniejów \\
\hline 5. & Jan Prądzyński & Uniejów \\
\hline 6. & Jan Oporowicz & Uniejów \\
\hline 7. & Józef Bamberski & Uniejów \\
\hline 8. & Bronisław Bagiński & Uniejów \\
\hline 9. & Maria Bagińska & Uniejów \\
\hline 10. & ks. Wiktor Rysztogi & Uniejów \\
\hline 11. & Władysław Stasiak & Uniejów \\
\hline 12. & Kazimierz Dybowski & Uniejów \\
\hline 13. & Józef Zieliński & Uniejów \\
\hline 14. & Juliusz Ponsyliusz & Uniejów \\
\hline 15. & Józef Andrzejewski & Uniejów \\
\hline 16. & Andrzej Zahorowski & Uniejów \\
\hline & & \\
\hline
\end{tabular}

Źródło: opracowanie własne.

Po dokonaniu analizy składu osobowego założycieli PCKB w Uniejowie można stwierdzić, że dominowali w niej mieszkańcy Uniejowa (93,75\%), mężczyźni $(93,75 \%)$, osoby świeckie $(87,5 \%)$. Nieznane są powody przystąpienia do inicjatywy założenia Kasy Antoniego Sasiaka - jedynego inicjatora niemieszkającego w Uniejowie, oraz Marii Bagińskiej - jedynej kobiety wśród założycieli. Prawdopodobnie zaważyły tutaj powiązania i znajomości między poszczególnymi założycielami, a w przypadku Marii Bagińskiej dodatkowo fakt, że przy zakładaniu stowarzyszenia brał udział jej mąż Bronisław.

\footnotetext{
${ }^{40}$ Tamże, s. 23-40.

${ }^{41}$ Tamże, s. 42.
} 


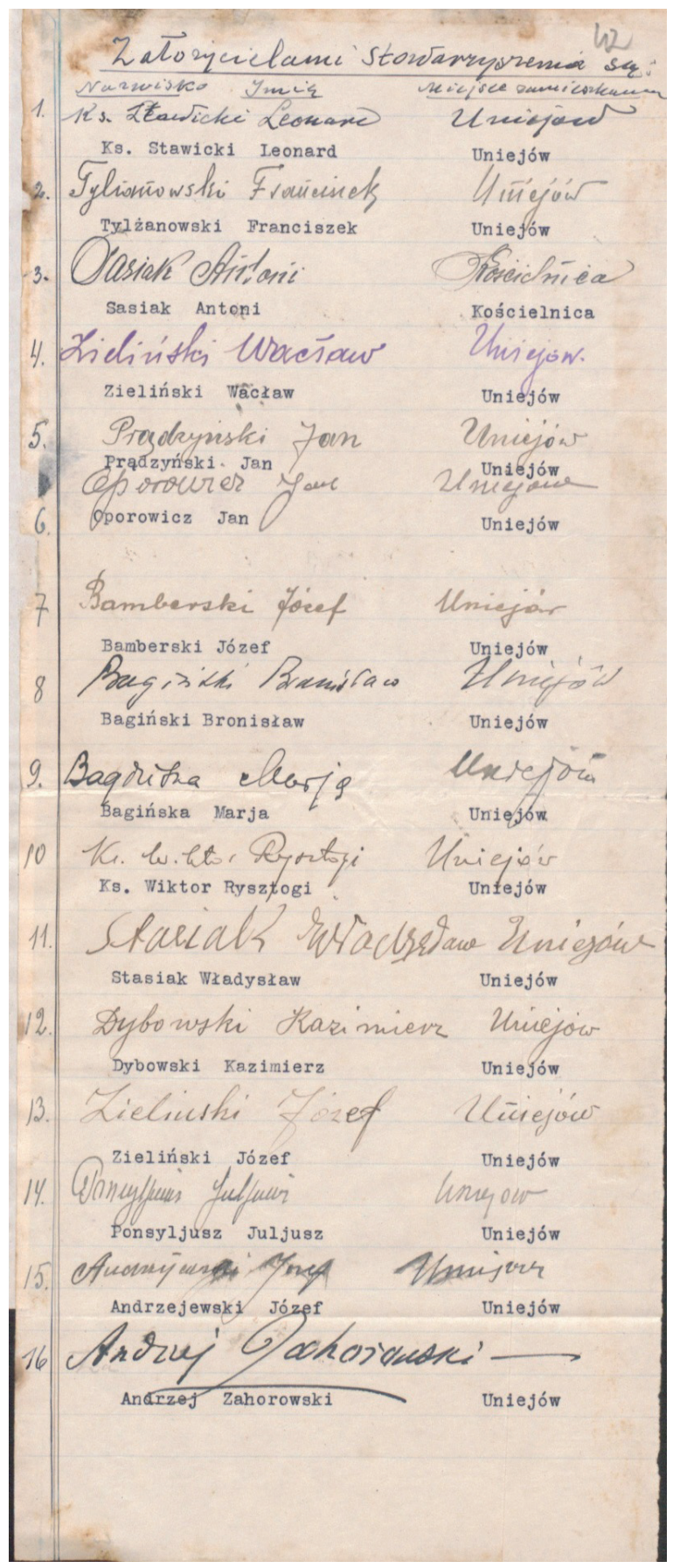

Ryc. 2. Lista założycieli Polskiej Chrześcijańskiej Kasy Bezprocentowej w Uniejowie z podpisami

Źródło: Archiwum Państwowe w Poznaniu 
W dokumentacji Kasy znajduje się także pismo określające skład zarządu stowarzyszenia. I tak, funkcję prezesa pełnił Józef Andrzejewski, sekretarza Franciszek Tylżanowski, skarbnika Józef Jaciak, natomiast członka zarządu Klemens Bojakowski ${ }^{42}$. Jak widać, w skład zarządu weszło jedynie dwóch założycieli Kasy, pozostałe dwie osoby pochodziły spoza tego grona.

O rozpoczęciu działalności Kasy w Uniejowie z dniem 12 marca 1937 r. Urząd Wojewódzki w Łodzi został poinformowany pismem stowarzyszenia z dnia 2 kwietnia 1937 r. Na piśmie można zauważyć odbitą okrągłą pieczęć uniejowskiej Kasy, na którą składał się napis otokowy „Polska Chrześcijańska Kasa Bezprocentowa” oraz w centrum „UNIEJÓW”43.

Ostatnimi dokumentami w teczce znajdującej się w zasobie Archiwum Państwowego w Poznaniu są pismo Urzędu Wojewódzkiego w Łodzi do Starosty Powiatowego w Turku z dnia 19 sierpnia $1938 \mathrm{r}$. dotyczące prośby stowarzyszenia w sprawie zmian statutowych z wnioskiem przychylnym, pismo stowarzyszenia z dnia 9 sierpnia 1938 r. w sprawie zmian statutowych, odpis protokołu Nadzwyczajnego Ogólnego Walnego Zgromadzenia Członków Kasy w Uniejowie, jakie odbyło się w dniu 23 lipca 1938 r. w celu zmiany statutu, oraz odpis pisma Zjednoczenia Chrześcijańskich Kas Bezprocentowego Kredytu w Rzeczypospolitej Polskiej z dnia 24 maja 1938 r. dotyczącego braków w statucie ${ }^{44}$. Jak wynika $\mathrm{z}$ treści ostatniego $\mathrm{z}$ tych dokumentów, Polska Chrześcijańska Kasa Bezprocentowa w Uniejowie, przyjmując swój statut, nie zapisała w nim, że zakładane stowarzyszenie jest członkiem Zjednoczenia Chrześcijańskich Kas Bezprocentowego Kredytu w Rzeczypospolitej Polskiej. Brakujące zapisy w statucie zostały uzupełnione na Nadzwyczajnym Ogólnym Walnym Zgromadzeniu Członków Kasy i następnie zatwierdzone przez Urząd Wojewódzki w Łodzi. Warto zauważyć, że znajdujący się w zachowanych dokumentach statut uniejowskiej Kasy to wersja z naniesionymi już w 1938 r. poprawkami.

Założona pod koniec 1936 r. Polska Chrześcijańska Bezprocentowa Kasa w Uniejowie, podobnie jak inne stowarzyszenia tego rodzaju, przestała istnieć najprawdopodobniej we wrześniu 1939 r. wraz z zajęciem Polski przez wojska III Rzeszy. Po wojnie jej działalność nigdy nie została wznowiona.

\section{PODSUMOWANIE}

Zachowane w zasobach Archiwum Państwowego w Poznaniu źródła pozwalają jedynie na poznanie pierwszego okresu działalności Polskiej Chrześcijańskiej Bezprocentowej Kasy w Uniejowie związanego z jej założeniem. Nie przetrwała jednak do naszych czasów dokumentacja odnosząca się do działań, dla których Kasa została założona, tj. udzielania pożyczek, fachowego doradzania, organizowania kursów i wykładów, czy też imprez dochodowych. Niemniej

\footnotetext{
42 Tamże, s. 43.

${ }^{43}$ Tamże, s. 44.

${ }^{44}$ Tamże, s. $45-48$.
} 
jednak zachowane dokumenty pozwalają na poznanie i prześledzenie choćby części historii tej nieznanej już w naszych czasach instytucji finansowej, która nierozłącznie wiąże się z dziejami Uniejowa i regionu.

\section{Bibliografia}

\section{Źródla}

Archiwum Państwowe w Poznaniu, Urząd Wojewódzki Poznański, Polska Chrześcijańska Kasa Bezprocentowa w Uniejowie powiatu tureckiego.

Ustawa w przedmiocie upoważnienia Ministra Skarbu do udzielania kooperatywom pracowników państwowych pomocy finansowej z dnia z dnia 13 lipca 1920 r. (Dz.U. Nr 62, poz. 399).

Rozporządzenie Prezydenta Rzeczypospolitej w sprawie zmian w ustawie z dnia 10 czerwca $1921 \mathrm{r}$. w przedmiocie utworzenia Państwowego Banku Rolnego z dnia 14 maja 1924 r. (Dz.U. Nr 43, poz. 450).

Rozporządzenie Ministra Skarbu w sprawie zmiany statutu Towarzystwa Kredytowego Przemysłu Polskiego z dnia 31 grudnia 1927 r. (Dz.U. 1928 Nr 7, poz. 49).

Rozporządzenie Prezydenta Rzeczypospolitej o prawie bankowem z dnia 17 marca 1928 r. (Dz.U. $\mathrm{Nr} 34$, poz. 321).

Rozporządzenie Prezydenta Rzeczypospolitej Kodeks handlowy z dnia 27 czerwca 1934 r. (Dz.U. $\mathrm{Nr} 57$, poz. 502).

Dekret Prezydenta Rzeczypospolitej o zmianie rozporządzenia Prezydenta Rzeczypospolitej z dnia 22 kwietnia 1927 r. o rozbudowie miast z dnia 14 stycznia 1936 r. (Dz.U. Nr 3, poz. 9).

Ustawa z dnia 15 września 2000 r. Kodeks spółek handlowych (Dz.U. z 2000 r. Nr 94, poz. 1037 ze zm.).

Ustawa z dnia 29 sierpnia 1997 r. Prawo bankowe (Dz.U. z 1997 r. Nr 140, poz. 939 ze zm.).

Rozporządzenie Parlamentu Europejskiego i Rady (UE) nr 575/2013 z dnia 26 czerwca 2013 r. w sprawie wymogów ostrożnościowych dla instytucji kredytowych i firm inwestycyjnych, zmieniające rozporządzenie (UE) nr 648/2012 z dnia 26 czerwca 2013 r. (Dz.Urz.UE.L Nr 176).

\section{Literatura}

Allerhand M., Kodeks handlowy. Komentarz, „Kodeks” Spółka wydawnicza, Lwów 1935.

Besala J., Banki i bańki, „Polityka”, nr 3 (2842) z dnia 18 stycznia 2012 r.

Białasiewicz M., Marek S., Podstawy nauki o organizacji: Przedsiębiorstwo jako organizacja gospodarcza, Polskie Wydawnictwo Ekonomiczne, Warszawa 2008.

Bornstein J., Kasy Bezprocentowych Pożyczek w Polsce, „Kwartalnik Statystyczny”, t. V, z. 3, Główny Urząd Statystyczny Rzeczypospolitej Polskiej, Warszawa 1928.

Bratkowski S., Nieco inna historia cywilizacji. Dzieje banków, bankierów i obrotu pieniężnego, VEDA Agencja Wydawnicza, Warszawa 2010.

Kon A., Kodeks handlowy. Komentarz, Księgarnia F. Hoesicka, Warszawa 1934.

Leszczyńska C., Zarys historii polskiej bankowości centralnej, Narodowy Bank Polski, Warszawa 2010.

Manteuffel T., Historia powszechna. Średniowiecze, PWN, Warszawa 2016.

Morawski W., Słownik historyczny bankowości polskiej do 1939 r., Wydawnictwo Muza S.A., Warszawa 1998.

W.F., Bezprocentowe Kasy Pożyczkowe, „Samodzielność”, nr 19 z dnia 1 października 1938.

Chrześcijańskie Kasy Bezprocentowego Kredytu, Związek Rzemieślników Chrześcijan w Warszawie, Warszawa 1937.

Mały rocznik statystyczny 1937, Główny Urząd Statystyczny Rzeczypospolitej Polskiej, Warszawa 1937.

Słownik finansów i bankowości, Wydawnictwo Naukowe PWN, Warszawa 2008. 


\section{Źródla internetowe}

http://encyklopedia.pwn.pl/haslo/banki;3874100.

http://www.polityka.pl/tygodnikpolityka/historia/1523347,3, historia-bankow-i-bankierow.read.

http://www.ushmm.org/wlc/en/article.php?ModuleId=10005367.

http://www.fakt.pl/historia-pieniadza/jak-ksztaltowala-sie-bankowosc-prywatna-w-polsce, artykuly,489722.html.

[Wpłynęło: styczeń 2016; akceptacja: maj 2016]

\section{THE POLISH CHRISTIAN LOAN ASSOCIATION IN UNIEJÓW}

\section{Summary}

The subject of the article is analysis of documents from the State Archive in Poznań concerning the activity of the Polish Christian Loan Association in Uniejów.

Keywords: Uniejów, Christian loan association, financial institution 